Ankara Üniversitesi Türk İnkılâp Tarihi Enstitüsü Atatürk Yolu Dergisi S 29-30, Mayts-Kasim 2002, s. 1-14

\title{
Atatürk'ün Ankara'ya Davet Ettiği Macar Profesör Antal Réthly'nin Türkiye'deki Çalışmaları
}

\author{
Yrd. Doç. Dr. Mithat ATABAY*
}

ÖZET

Cumhuriyetin kurulduğu yıllarda ekonomisi tarıma dayanan Türkiye, toprağın ve suyun verimli kullanılması gerektiğinden hareketle; meteoroloji, hidroloji ve sulama işlerinin düzenlenmesi, toprağın ıslah edilmesi çalışmalarını öncelikle ele aldl.

Atatürk bu konularda çalışma yapacak Alman, Macar, Sovyet, Fransız, İtalyan ve Hollandalı uzmanları Türkiye'ye davet etti. Prof.Dr. Antal Réthly Kasım 1925'te Türkiye'ye geldi.

Prof. Réthly tarafindan hazırlanan iklim etüdü, Ankara'nın şehirleşme planını yapacak olan Prof. Janssen'e tşık tutacaktır.

Anahtar Kelimeler: Prof. Dr. Antal Réthly, Ankara'nın şehirleşme planı, Prof. Dr. Janssen

Works of Prof. Dr. Antal Réthly Who was invited to Ankara by

\section{Atatürk}

\section{ABSTRACT}

The importance is given to establish meteorology, hydrology, irrigation and increasing productivity soil in order to use of profitable water and soil in the first years of rupublic in Turkey.

- Çanakkale Onsekiz Mart Üniversitesi, Fen-Edebiyat Fakültesi, Tarih Bölümü. 
Atatürk has invited the prefessions who will be searched on this subject matter from Germany, Hungary, Soviets, France and Netherland. Prof. Dr. Antal Réthly has come to Turkey in November 1925.

This study has been a reference for Janssen in order to prepare Ankara City Plan. This study is also a source for Ankara Climate studies.

Key words: Prof.Dr. Antal Réthly, Ankara City Plan, Prof. Dr. Janssen

\section{Giriş}

Cumhuriyet ideolojisinin temeli, Tanzimat'tan Cumhuriyete kadar Türkiye'nin nasıl kurtulacağının cevabıdır. Bu cevap, artık tarihsel sürecini tamamlamış olan ve yıkılmaya yüz tutmuş bir imparatorluğun yerine yeni anlayışa sahip yeni bir toplum oluşturmayı amaçlamaktadır. Tabî̂ ki bu anlayışın doğal sonucu çağdaşlıktır. Yani dünyadaki gelişmelerin merkezinde olabilmek, onlarla at başı gidebilmektir.

Cumhuriyet ideolojisinin gerçekleştirilmesi, yeni anlayışa dayanan yeni devletin sürekli yükseliş trendi izlemesi için yeni kurumlar oluşturulmasını gerektirmektedir. Yeni kurumlar oluşturulurken, yeni dünya görüşü esastır ve bu dünya görüșünün dayandığı prensipler çerçevesinde oluşturulacak kurumsallaştırma devletin etkinliğine paralel olarak, yeni kültür-uygarlık etkin kılınacaktır'.

$\mathrm{Bu}$ anlayış çerçevesinde, Cumhuriyet'in kuruluş döneminde yeni bir kurum ortaya çıkmıştı. O zamana kadar doğanın oluşumu, tabiat hadiselerinin araştırılması, gözlemlenmesi zararlı bilimler kapsamında kalmıştır ${ }^{2}$. Cumhuriyetin ilânından sonra, her alanda çağdaş ülkeler

${ }^{1}$ Batıda akılcılık, bilgi ve bireye dayanan aydınlanma felsefesi ile çağdaşlaşma gerçekleştirilmiştir. Aydınlanma felsefesi için bkz., Macit Gökberk, "Aydınlanma Felsefesi, Devrimler ve Atatürk," Çağdaş Düşüncenin Işı̆̆ında Atatürk, 2.Baskı, İstanbul 1986, s. 281332; Ayr. bkz., Niyazi Berkes, Türkiye'de Çağdaşlaşma, 2.Baskı, İstanbul 1978.

${ }^{2}$ Şerafettin Turan (Türk Kültüründen Türkiye Kültürüne ve Evrenselliğe, Ankara 1990, s.174-184)'a göre; XVI. yüzyılın son çeyreğinde bilimler üçe ayrılmıştır. Birinci grup zorunlu bilimler (şer'i, dinî bilimler), ikincisi mendup olanlar (tıp, geometri, cebir,vb.) ve zararlı bilimler (felsefe, astronomi, kozmografya)'dır. Eğitim sistemi de bu ayırım çerçevesinde yeniden düzenlenmiștir. Üçüncü gruba girmesi dolayıstyla İstanbul Rasathanesi de topa tutularak yıkılmıştır. N. Gökdoğan ("Tanzimat ve Müspet Illimler, Tanzimat I, İstanbul 1940, s.470) da, "Mamafih bu ilk rasathanenin ömrü pek kısa sürmüştür. Sadettin Efendi ile rekabetinden dolayı Şeyhülislâm Şemseddin Efendi rasat yapmanın şeabet getireceğine dair 'ihracı rasat meş'um ve perde-i esrar-1 felekiyeye küstahane 1 ttılaa cür'etin vehameti meczumdur; hiçbir mülkte mübaşeret olunmadı ki mamur harap ve bünyan-1 devleti zelzelenakî inkılâp olamaya' mealinde ve Hülagu İlhan ile Uluğ Bey'in meş'um akibetlerini telmih yollu padişaha bir jurnal vermiş ve bunun üzerine Kaptan-1 Derya Kılıç Ali Paşa 
seviyesine çıkmak ve toplumun ihtiyaçlarının çağdaş ülkeler seviyesindeki kurumlarla karşılanması için kurumsallaşma dönemine girilmiş ve her alanda olduğu gibi tarım, ulaşım, şehircilik, orman, çevre, savunma gibi sektörlerin meteorolojik bilgi ihtiyaçlarını karşılamak üzere Rasadat-l Cevviye Müessesesi adı ile bir kurum oluşturulmuştur. Rasadat-1 Cevviye Müessesesi'nin kurucusu Prof. Dr. Antal Réthly’dir.

\section{Prof. Dr. Antal Réthly'nin Türkiye'ye Gelişi}

Cumhuriyet'in ilânından sonra Türkiye'de siyasal, ekonomik ve kültürel inkılâplar gerçekleştirilmeye başlandı. Ekonomisi tarıma dayanan Türkiye, toprağın ve suyun verimli kullanılması gerektiği düşüncesinden hareketle; meteoroloji, hidroloji ve sulama işlerinin düzenlenmesi, toprağın ıslah edilmesi çalışmalarını öncelikle ele ald $^{3}$.

Atatürk bu konularda Türkiye'de çalışma yapmak üzere Alman, Macar, Sovyet, Fransız, İtalyan ve Hollandalı uzmanları davet etti. İsmet Paşa'nın Başbakanlığını yaptığı Cumhuriyet Hükümeti $;{ }^{4}$ meteoroloji çalışmalarını yürütmek için, Budapeşte Rasathanesi Şube Müdürlerinden Prof. Dr. Antal Réthly'i görevlendirdi ${ }^{5}$.

1879'da Macaristan'da doğan Prof. Dr. Antal Réthly, Budapeşte Üniversitesi'nde öğretim üyeliği ve coğrafya doktorası yaptı. Deprem araştırmaları için 1904'te Ogyalla' da üniversitede göreve başlayarak, 1914'e kadar araştırma çalışmalarını sürdürdü. Daha sonra Romanya'da Kluj Üniversitesi'nde edebiyat doktoru unvanını aldı. Bu arada Meteoroloji Enstitüsü İklim Araştırma Bölümü asistanı oldu. Macaristan'da İdöjárás (Hava Koşulları) adlı gazeteyi çıkarmaya başladı. 1925'ten sonra Londra'da Society of Medical Hydrology kurumu üyeliğine kabul edildi. Pek çok

rasathaneyi bir gece içinde hak ile yeksane me'mur etmişti (1579, 21 İkincikanun, Perşembe)." demektedir ; Ayr. bkz., Süheyl Ünver, İstanbul Rasathanesi, Ankara 1969.

${ }^{3}$ Fethi (Okyar) Bey'in kurduğu hükümetin (14.8.1339-24.10.1339) programında tarıma oldukça geniş yer verilmiştir. Programda şöyle deniliyor: "Memleketimizin en mühim şube-i iktisadiyesinin ziraat olduğu bedihi bir keyfiyettir. Ziraatın himayesi ve inkişafı için ihtisas ziraat mektepleri açılacaktır..."bkz., Türkiye Cumhuriyeti Hükümet Programları, Yay. Haz. Kazım Öztürk, İstanbul 1968, s.44.

${ }^{4}$ Türkiye'nin doğusunda Şeyh Sait İsyanı çıkması üzerine 4 Mart 1925 tarihinde İsmet Paşa Başbakanlığa getirilmişti.

${ }^{5}$ T.C. Ziraat Vekâleti, Meteoroloji Enstitüsü Tarihçesi, Teşkilâtı, Hizmetleri, İstanbul 1933, s.1.; Ayr. bkz., A. Maygar Földrajzi Tarsasag Veszteségei Az Elmult Masfel Evben, Sermo, Supra Sepulcrum Antal Réthly, Kötef 1976, s.122-124.; Vecdet Erkun, Budapeşte'den Ankara'ya, Ankara 1999, s.44, 88-89. 
bilimsel çalı̧̧ması bulunan Prof. Dr. Antal Réthly, 96 yaşında 21 Eylül 1975 'te hayata gözlerini yummuştur ${ }^{6}$.

\section{Prof. Dr. Antal Réthly'nin Türkiye'deki Çalıșmaları}

Hükümet, 1925 yılında Ziraat Vekâleti'ne bağlı olarak bir meteoroloji servisi kurulmasını Prof. Dr. Antal Réthly'den istemiş ve kendisiyle iki yıllık bir sözleşme yapmıştır. Ön hazırlıklardan sonra 12 Kasım 1925'te Ziraat Vekâleti'ne bağlı olarak Rasadat-ı Cevviye (Meteoroloji Enstitüsü) ismi ile Etlik'te meteoroloji kurumu faaliyete başlamıştır.

Etlik'te faaliyete geçen meteoroloji istasyonunda 12 Kasım 1925 tarihinden itibaren basınç, sıcaklık, buhar basıncı, havanın nispi nemi, bulutluluk, rüzgâr, meteorolojik hadise gözlemleri hemen başlamış, ayın 20 'sinden itibaren de azami ve asgari sıcaklık ölçümlerine başlanmıştır.

Prof. Dr. Réthly’nin meteorolojik çalışmalarını üç başlık altında incelemekte yarar vardır.

a. Ankara'daki gözlemler ve gözlem sonuçlarının yayınlanması

b. Meteoroloji istasyonlarının Türkiye çapında yaygınlaştırılması

c. Ankara'nın şehirleşmesi konusunda hazırladığı rapor

a. Ankara'daki Gözlemler ve Gözlem Sonuçlarının Yayınlanması

Prof. Dr. Antal Réthly, Ankara'da yapılan gözlemler ile ileride yurt düzeyine yayılacak olan meteoroloji istasyonlarının gözlem sonuçlarını düzenli şekilde yayınlamıştır.

Göreve başlamasının ilk ayında Rasadat-ı Cevviye Risalesi ${ }^{7}$ adı altında dört sayfadan oluşan bir bülten çıkarmaya başlamıştır. İlk sayısı İkinciteşrin 1925 (Kasım 1925)'te yayınlanmıştır.

Bu sayıda Ziraat Vekili Sabri Bey'in, ${ }^{8}$ Rasadat-1 Cevviye'nin kurulması için Prof. Dr. Réthly'e görev verdiği ve Etlik'te kurulan rasathanenin alet ve

${ }^{6}$ Macar Türkolog Maria Nyiri, Antal Réthly hakkında 1991 yılında Budapeşte'de bir seminer çalışması yapmıştır. Bu çalışmadan büyük yararlanma imkanım oldu. Bkz., Maria Nyiri, Meteorolog Antal Réthly 1879-1975, Budapest 1991.; Prof. Dr. Antal Réthly'nin hayatı için Ayr. bkz., Ragar Agrartirteirefe E'letrayzok Für Lagos ès Piapér Jaios, Réthly Antal (1879-1975), Budapest 1989, s.61-66.

${ }^{7}$ Risale harf inkılâbından önce yayınlandığı için eski harflerle 500 adet basılmış ve dört sayfadan olușmaktadır. Türkiye Cumhuriyeti Rasadat-1 Cevviye Müessesesi, Aylık Rasadat-l Cevviye Risalesi, sene:1, numara:1 (İkinciteşrin 1341). Risale, 1933 yılında Aylık Hava Bülteni ismi altında iki cilt olarak yeni harflerle o zamanki Meteoroloji Enstitüsü Müdürü Profesör Ahmet Tevfik Göymen tarafından tekrar yayımlanmıştır.

8 Ziraat Vekili Mehmet Sabri (Toprak) Bey, 1877'de Kasaba'da doğdu. Darüşşafaka'dan sonra Hukuk Fakültesi'ni bitirdi. Osmanlı Mebusan Meclisi'nde 2. ve 3 . dönem Saruhan mebusu oldu. Cumhuriyet döneminde PTT Umum Müdürlüğü görevinde 
cihazlarının Macar Kraliyet Hükümetince verildiği belirtilmiștir. Ayrıca aletlerin teknik özellikleri, hata miktarları ile gözlemlerin yapılış zamanları hakkında bilgiler verilmiştir. Ankara Observatoriyomu Rasatları başlı̆̆ altında gözlem sonuçları yayınlanmış ve Beynelmilel Meteoroloji İsaretleri'ne yer verilmiştir.

Söz konusu bülten, her ay düzenli şekilde yayınlanmaya devam edilmiştir. Bülteni Prof. Dr. Réthly hazırlamakta ve yardımcısı, aynı zamanda tercümanı olan Ziraat Mühendisi Süreyya Sadık Bey de Türkçe'ye çevirmektedir.

Bültenin diğer sayılarında, Ankara'daki gözlemlerin değerlendirilmeleri, yeni açılan istasyonların isimleri ve buralardan ölçülen yağı̧̧ miktarları ile Etlik'teki gözlemler ve Ankara şehri içindeki tespitlere yer verilmiştir. Ankara'daki görülen sisler hakkında Prof. Dr. Antal Réthly'nin tespiti şöyledir ${ }^{10}$ : "Bu ay zarfinda Ankara üzerinde 21 defa sis rasat edilmiştir. Sabahleyin müşahade olunan sisler güneşin tuluundan sonra kesb-i kesafet eylemekte ve 11 ilâ 1130'a kadar devam etmekte idiler. Sis bilhassa Incesu'yun mecrası üzerinde pek kesif bir tabaka halinde bulunmakta idi." Prof. Dr. Réthly'nin, Etlik'te yaptığı fenoloji gözlemleri daha da ilgi çekicidir". "Tabiatın uyandı̆̆ı bu ayda Etlik'te onikinci gün ilk kertenkele, ondördüncü gün ilk sivrisinek ve aynı gün de Ankara'da August sütunu üzerinde ilk leylek, ayın yirmiikinci gecesi de ilk gece kelebekleri görülmüş ve ay sonunda bütün ağaçlar çiçeklenmiştir." Prof. Dr. Réthly, Türkiye'de meydana gelen depremler hakkında da bilgi vermiş ve Erzurum'da meydana gelen deprem için "Yirmidokuz Nisan'da saat 1603'te Erzurum'da Erzurum'da hafif bir zelzele olmuştur." diye kayıt düşmüştür ${ }^{12}$.

Prof. Dr. Antal Réthly'nin, Ankara'nın iklim etüdünde de yer verdiği genellemeleri ilgi çekicidir"13: "10 Temmuz'da başlayan kuraklık 8 Eylül 'de

bulundu. 2. dönem Saruhan, 3. dönem Cebelibereket, 4. ve 5. dönem Manisa'dan milletvekili seçildi. Elçilik yaptı. 3. İsmet Paşa Hükümeti'nde (4.3.1925-1.11.1927) Ziraat Vekili oldu. 19.2.1938'de öldü. Bkz., TBMM Albümü 1920-1973, Yay. Haz. Kazım Öztürk, Ankara 1973, s.102.

${ }^{9}$ Süreyya Sadık Bey, Halkalı Ziraat Mektebi'nden mezun oldu. I.Dünya Savaşı sırasında Almanlarla ortaklaşa kurulan Rasadat-1 Havaiye İdaresi'nde görev aldı. 12 Kasım 1925 'te kurulan Rasadat-1 cevviye Müessesesi'nde Antal Réthly'nin yardımcısı ve asistanı oldu. Réthly ile birlikte Türkiye'de bir çok meteoroloji istasyonunun kurulmasında görev aldı. 1930 yılı Ocak ayında bir bombanın patlaması sonucunda elim bir şekilde vefat etti. Bkz., Ziraat Vekâleti Meteoroloji Enstitüsü, Aylık Hava Bülteni 1925-1926, 2.Tabı, Ankara 1933, s. 4.

${ }^{10}$ Aylık Hava Bülteni, sene: 2, sayı: 3 (Mart 1926), s.1.

"Aylık Hava Bülteni, sene: 3, sayı: 3 (Mart 1927), s.1.

${ }^{12}$ Aylık Hava Bülteni, sene: 2, sayı: 4 (Nisan 1926), s.1.

${ }^{13}$ Aylık Hava Bülteni, sene: 2, sayı: 9 (Eylül 1926), s.1. Prof. Dr. Réthly'nin bu konudaki bir başka değerlendirmesi ise şöyledir "...Ankara vadisinde yirmidokuz gün müddetle her gün saat (1/-13)'e kadar devam eden ve bazen Kale'nin fevkine kadar çıkan 
nihayet bulmuştur. Pek uzun devam eden bu kuraklık vasi bir step ortasında bulunup araba, otomobil gibi vesait-i nakliyesi kesir olduğu gibi dahilinde bir çok inşaat yapılan Ankara için bilhıfzıssıha nokta-i nazarından çok tehlikelidir. Heman heman her gün bir çok saat müddetle Ankara'nın toz bulutları ile mestur kaldı ̆̆ rasat edilmistir. Sokakların tesiri yarım saatten fazla devam etmeyen su ile sulanması yerine petrolle sulanması pek büyük faideler temin edecektir."

Prof. Dr. Réthly, Türkiye'den ayrıldıktan sonra, Cumhuriyetten önce İstanbul'da Erenköy'deki Thomson Çiftliği'nde 1875-1893 yıllarında yapılan gözlemleri Macar Coğrafya Cemiyeti'nin yayın organında 1928 ve 1930 yılında neşretmiştir ${ }^{14}$.

1931 yılında basılan Türkiye Yağmur Vaziyeti Bülteni hakkında Az Idöjàràs'ta yazdığ 1 makalede Prof. Dr Réthly, "Bir ilmî neticeyi șimdiden çıkarabiliriz. İç Anadolu'daki yağış miktarı benim daha evvelki tahminlerimi takviye etmektedir. Çünkü eski rakamlardan daha yüksek kıymetler göstermektedir..." derken, yazısının sonlarına doğru da "Bu Türk müessesesinin Anadolu ikliminin tanınmasına hadim maddeleri kendi gücü ile başarmak hususundaki muvaffakiyetlerini tebrik etmek iktiza edecektir." demektedir ${ }^{15}$.

Prof. Dr. Antal Réthly'i en mutlu eden bir konu da, Türkiye'de ilk defa iklim bilgilerinin 1927 yılı Eylül ayı sonunda Ankara Radyosu'ndan yayınlanması olmuştur ${ }^{16}$.

\section{b. Meteoroloji İstasyonlarının Türkiye Çapında Yaygınlaştırılması}

Osmanlı İmparatorluğu'ndan Türkiye Cumhuriyeti'ne meteoroloji alanında miras olarak sadece Kandilli Rasathanesi kalmışıır ${ }^{17}$.

Prof. Dr. Antal Réthly, Türkiye iklimi hakkında bir șeyler söylenebilmesi için meteoroloji istasyonlarının yaygınlaştırılması düşüncesinden hareketle çalışmalarına başlamıştır. Ancak çalışmaları sırasında pek çok ekonomik, bürokratik ve kültürel zorluklarla karşılaşmıştır.

ratıp ve yabis sisler rasat edilmiş ve şehir bilhassa öğleden sonraları tozla kaplı kalmıştır. Bundan başka istasyon civarında kain fabrikaların dumant da şehrin üzerine bulut gibi örtüp havayı ifsat etmekte olduğundan şehir civarında fabrikaların tezayüdü sıhhat-i umumiyeye fena tesirler yapacaktır.” Bkz.; Aylık Hava Bülteni, sene: 2, sayı: 11 (İkinciteşrin 1926), s.1.

${ }^{14}$ Dr. Antal Réthly, "Sztambul-Erenköi Csapadékviszonyai (Kisázsia, 1875-1892)," Az. Idöjàràs, Budapest 1928, s.213-229.; Ayr. bkz., Dr. Antal Réthly, "İstanbul-Erenköi Hömérsékleti Megfigyeléseiböl (Kisázsia 1875-1892)," Az Idöjàràs, Budapest 1930, s.178184.

15 T.C. Başvekâlet DMİ Umum Müdürlüğü, Cumhuriyetin 15 Yll içindeki Eserlerinden Biri, Ankara 1938, s.23.

${ }^{16}$ Nyiri, a.g.e., s.17.

${ }^{17}$ M. Atabay, "Meteoroloji Tarihi: Bir Miras Rasathane-i Amire," Lodos, sayı: 4 (Mayıs 1994), s.20-22. 
Prof. Dr. Antal Réthly, işe başladığı zaman kendisine verilen vaatler ve destekler konusunda şöyle diyor: "Ankara'da bir enstitï kurmak fevkalâde zor bir görevdi. Illk günlerde ödedikleri aylık maaş dışında başka şeyler için bir kuruş bile ödemek istemiyorlardı. Çalışmalarımın başarılı olabilmesi için gerekli desteği eninde sonunda sağlayabildimse bunu Devlet Müsteşart Süreyya Mehmet Bey'e borçluyum. Mecliste kabul edilen bir karar uyarinca, devlet bütçesine yeni maddeler eklenemezdi. Oysaki beni, bazı örgütsel çalışmalarla görevlendirmişlerdi. Ziraat Vekili Sabri Bey ile Maliye Vekili Behiç Bey'den gördügüum destek güçlükleri çözdü. Nihayet Ankara'da yaptırdı ̆̆ım termometre donanımlarını ülkenin her yerine gönderdim." 18

O, örgütlenme çalışmalarını yürütmek üzere Türkiye'de toplam onyedibin kilometre yol kat etmiştir. Bu gezilerin, Türkiye'nin o zamanki ulaşım olanakları gözönünde tutulduğunda ne kadar zor olduğu anlaşılabilir. Geziler genellikle trenle, bazen otomobille, deniz kenarındaki şehirler arasında gemiyle bazen de at sırtında yapılmıştır.

Gezilerde Prof. Dr. Antal Réthly'nin yanında yardımcısı Süreyya Sadık Bey de bulunmuştur. Prof. Dr. Réthly, meteorolojik aletleri bizzat kendisi kurmuş, gerekli eğitim çalışmalarını ise yardımcısıyla birlikte yürütmüştür. Prof. Dr. Antal Réthly, meteoroloji istasyonlarının yaygınlaştırılması için her biri oldukça uzun sayılabilecek dört gezi yapmıştır. İlk örgütlenme çalışmasına İstanbul ve Trakya çevresinden başlamıştır. 1926 yılının başında önce Kandilli Rasathanesi'nin çalışmalarını incelemek üzere İstanbul'a giden Prof. Dr. Antal Réthly, buradan Edirne'ye geçmiş ve orada Ankara'dan sonra ilk meteoroloji istasyonunu kurmuştur. Örgütlenme çalışmalarını yürütmeye başladığında Prof. Dr. Antal Réthly, Ankara'daki çalışmalarını yürütmek için de Jòzsef Szemián'ı görevlendirmiştir ${ }^{19}$. Trakya gezisinden sonra ikinci olarak Eskişehir, Konya ve Orta Anadolu gezisine çıkan Prof. Dr. Antal Réthly, buralarda meteoroloji istasyonları kurarken; aynı zamanda bitki örtüsü, su kaynakları ve toprağın yapısını da inceleme fırsatı bulmuştur. Prof. Dr. Antal Réthly'nin üçüncü gezisi, 1926 yılı Yaz aylarında Adana'dan başlamak üzere Adana, Antalya, Muğla, Aydın, İzmir ve Bursa illerine olmuştur. Çok değişik iklim ve bitki örtüsüyle karşılaşan Prof. Dr. Antal Réthly, daha sık meteoroloji istasyonunun kurulması için girişimlere başlamıştır. Ancak Réthly'nin bu girişimleri kısa bir süre için sekteye uğramıştır. 1926 yılı içerisinde Musollini "İtalya İtalyanlar için dardır" $^{20}$ sloganı ile Batı ve Güney Anadolu bölgeleri üzerinde hak iddiasında bulunmuştur. Bunun üzerine Türkiye seferberlik hazırlıklarına girişmiştir. Seferberlik giderleri, meteorolojiye ve diğer alanlara ayrılan yatırım ödeneklerinin dondurulmasına neden olmuştur. 1926 yılı sonunda Türkiye'nin Batı, Güney, Trakya ve Orta Anadolu Bölgelerinde iklim

\footnotetext{
${ }^{18}$ Nyiri, a.g.e., s. 9.

${ }^{19}$ Nyiri, a.g.e., s.10.

${ }^{20}$ Mehmet Gönlübol, ve diğerleri, Olaylarla Türk Dış Politikası, c.I, 6.Baskı, Ankara
} 1987, s.82. 
çalışmaları için gerekli meteorolojik veriler düzenli bir şekilde elde edilmeye başlanmıştır.

Yine Prof. Dr. Antal Réthly'nin girişimleri ile 3 Mayıs 1927 tarihinde yeni bir meteoroloji merkezi binasının inşaatına başlanmıştır. İnşaat başladıktan hemen sonra Prof. Dr. Antal Réthly, Türkiye'deki son yolculuğu olan Karadeniz ve Doğu Anadolu'nun kuzeyini kapsayan geziye çıkmıştır. Zonguldak ve Sinop'a uğramış, Sinop'a gelirken Türkiye'deki araştırma ve incelemelerini içeren notlarının bulunduğu çantayı kaybetmiştir ${ }^{21}$.

Sinop'tan karayolu ile Karadeniz sahillerini dolaşmış; Samsun, Trabzon ve Rize'ye uğramıştır. Trabzon'da oldukça ilginç üç olayla karşılaşmıştır. Bu üç olay, o dönemin anlayışını kavrayabilmemiz için ilginçtir.

Prof. Dr. Antal Réthly, Trabzon'da incelemelerde bulunduğu sırada liman polisi tarafından tutuklanmıştır. Bilimsel incelemeler için İçişleri Bakanlığı'nın kendisine verdiği izin belgesini polis dikkate almamıştır. Polis komiseri, bilim adamlarına ve İçişleri Bakanı'na karşı saygılı olduğunu belirttikten sonra "Bildiğiniz gibi bu çevrenin sorumlusu benim, beyefendinin casus olduğu anlaşılırsa bunun cezasını Bakan Bey değil ben çekerim" diyerek çalışmalarını engellemiştir ${ }^{22}$. Ayrıca Prof. Dr. Antal Réthly, tarımı daha çok ilgilendirdiği halde meteorolojik gözlemleri tarım öğretmenlerinin yapmak istememelerini anlayamamıştır. Trabzon ve Rize'de kurduğu istasyonların bürokratik sebeplerle sökülmesine anlam verememiştir. Trabzon'dan Erzurum'a geçmiş ve Erzurum dönüşü Trabzon'da sökülen iklim istasyonunun yerine bir yă̆ı̧̧ istasyonu kurmuştur. Prof. Dr. Antal Réthly'nin bu yolculuk sırasında parası kalmamıştır. Prof. Dr. Antal Réthly, "Avans alabileceğimi söylediler. Öyle ama yolculuğum sona erdikten sonra hesap vermek için yeniden Trabzon'a mı döneyim?” demiştir ${ }^{23}$.

Ankara'da kurulan meteoroloji merkezinin inşaatının sona ermesi ile Etlik'teki rasathane, 15 Ekim 1927 tarihinde yeni binasına taşınmış ve orada gözlemlere başlanmıştı. Prof. Dr. Antal Réthly burada gerekli cihaz ayarlarını da yapmışt1 ${ }^{24}$. "Yeni enstitüde barometre rasadatı; 1-20 Birinciteşrin'de icra edilmiş olup, korreksiyonu +0.73 milimetredir. 20 Birinciteşrin'den itibaren barometre rasadatı 1459 numaralı Thurneyssen barometresi ile icra edilmiş olup, mezkur barometre üzerine nakliyat esnasındaki tahsisat korreksiyonu ilâve edilmek suretiyle nazar-ı itibare alınmıştır. Bilumum barometre irtifaları 1459 numaralı Thurneyssen barometresine ve yeni rakıma ( 860.8 metre) göre irca edilmiştir. Suhunet

${ }^{21}$ Sinop’ta Hava Rasat Müdürü olarak Yüzbaşı Şakir Bey görevlendirilmişti. Prof. Dr. Antal Réthly, Yüzbaşı Şakir Bey'in kahve içme davetini kabul etmiş, kahvenin pişmesinin uzun sürmesi geminin iskeleden ayrılmasına neden olmuştur. Bkz., Nyiri, a.g.e., s.13.

${ }^{22}$ Nyiri, a.g.e., s.13.

${ }^{23}$ Nyiri, a.g.e., s. 15 .

${ }^{24}$ Aylık Hava Bülteni, sene: 3, sayı: 10 (Birinciteşrin 1927), s.1. 
radatı, 15 Birinciteşrin'e kadar Etlik'te ve 16 Birinciteşrin'den itibaren yeni Enstitüde yaptlmıştır. Korreksiyon yeni Enstitünün bulunduğu mahalle göre irca ve icmal edilmiştir. 11-15 Birinciteşrin Ingiliz siperinde, bundan başka Asman Aspirasyonlu Psikrometresi ile rutubet rasadatı icra edilmiştir. Eski ve yeni istasyonlarda ayn zamanda muvazi olarak rasat icrası maalesef mümkün olmamıştır."

Türkiye'de bulunduğu yaklaşık iki yıllık sürede; bizzat yirmibeş tanesini kendisinin kurduğu toplam yetmişaltı tane çeşitli tip ve büyüklükteki meteoroloji istasyonlarından oluşan gözlem şebekesini oluşturan Prof. Dr. Antal Réthly, bu meteorolojik gözlem șebekesinden sadece onüç istasyonda çeşitli sebeplerle düzenli gözlem yaptıramamış olmakla birlikte üzerine aldığı görevi başarmanın rahatlığ 1 içerisinde 30 Ekim 1927 tarihinde ülkesine dönmüştür.

1929 yılında Türk Hükümeti, beş yıllık bir dönem için yeniden Prof. Dr. Antal Réthly'e teklif yapmışsa da Réthly, "Maalesef öneriyi kabul edemedim. Türk halkını fevkalâde sevmeme rağmen fedakârlıkta bulunmak ve ana yurdumda kalmak zorundayım" diyerek öneriyi kabul etmemiştir ${ }^{25}$.

Atatürk, 1927 yılında Prof. Dr. Antal Réthly'i meteoroloji alanında yaptığı başarılı çalışmalarından dolayı yüksek devlet nişanıyla taltif etmiştir ${ }^{26}$.

c. Yeni Başkent Ankara'nın Şehirleşme Planı İçin Hazırlanan Meteorolojik Rapor

27 Aralık 1919 tarihinde Heyet-i Temsiliye'nin Ankara'ya gelişiyle Ankara, Kurtuluş Savaşı'nın merkezi olmuştur. Mustafa Kemal Paşa ve arkadaşları bugün Meteoroloji Genel Müdürlüğü binası olarak kullanılan Ziraat Mektebi'ne yerleşmişler ve çalışmalarını buradan yürütmeye başlamışlardır.

Kurtuluş Savaşı ve sonrasındaki gelişmeler Ankara'nın yeni devletin merkezi olacağını göstermektedir. 30 bin nüfuslu Ankara'nın savaştan sonra başkent olmasını istemeyen İngiltere, Lozan Antlaşması'ndan sonra diplomatik bir savaş başlatarak bunu engellemeye girişmiştir. Bunun için Fransa, İtalya, Japonya ve Amerika Birleşik Devletleri'ne bir nota göndererek Türk Hükümeti nezdinde Ankara'ya atanacak temsilcilerin "elçi mi?" yoksa "büyükelçi mi?" olacağını ve bunların "İstanbul'da mı?" yoksa "Ankara'da mı?" oturacaklarını sormuştur. Türkiye bu dış baskılara boyun eğmemiştir. Ülke içinde de yeni başkentin neresi olacağı konusunda tartışmalar yapılmaya başlanmıştır. Kurtuluş Savaşı'nın ünlü komutanlarından Refet Bele Ankara'nın başkent olmasını kabul etmediğini açıklamışı̧ır.

\footnotetext{
${ }^{25}$ Nyiri, a.g.e., s.19.

${ }^{26}$ Nyiri, a.g.e., s.2 ve s.19.
} 
Bu tartışmaların yapıldığı sırada Lozan Antlaşması gereği İstanbul'da bulunan İtilaf Kuvvetleri tahliye edilmiş ve 1923 yılı Ekim ayı başında tüm memleket işgalden kurtulmuştu. Mustafa Kemal ile mutabakat halinde bulunan Dışişleri Bakanı İsmet Paşa ve ondört arkadaşı 9 Teşrinievvel 1339'da (9 Ekim 1923) Ankara'nın bașkent olması için “Türkiye Devleti'nin makarrı idaresi Ankara şehridir" teklifini Meclise vermişler ve bu teklif 13 Ekim 1923'te kabul edilmiştir. Ankara'nın başkent olduğuna dair karar 20 Nisan 1924 tarihli Anayasanın 2.maddesinde de yer almıştır.

İngiltere, Ankara'nın başkent olmasından sonra da direnişine devam etmiş, büyükelçisi İstanbul'da ikâmet ederken Ankara'da bir temsilci bulundurmaya başlamıştır. Diğer devletler de aynı yolu izlemişlerdir. Sadece Ankara'da Sovyetler Birliği, Afganistan, Gürcistan, Ukrayna ve İran'ın büyükelçileri bulunuyordu. Gerek yabancı devletler gerekse Ankara'nın başkent olmasına karşı çıkanlar "Bir müddet yerleşmek için uğraşılır, sonra tekrar İstanbul'a dönülür’” düşüncesini taşımışlardır ${ }^{27}$.

Hatta eleştiriler o boyutta idi ki, "Ankara merkezliği geçici bir şeydir. Sıfırın üstünde medeniyet olmaz. Onun için buraya masraf etmemeliyiz" deniliyordu. Bir başka eleştiri ise şöyleydi: "Bir müddet kalırız. Yerleşmeye uğraşırız. Sonunda İstanbul'a gitsek bile, sıkışınca Anadolu'da taşınabilecek bir merkez edinmiş oluruz... Bu yüksekliğe kalp dayanmaz. Ankaralı Ermeniler bile ellisine gelince İstanbul'a göçerlermiș." 28

Cumhuriyetin ilânından sonra Ankara'nın başkente yakışır hale getirilmesi için imar çalışmalarına başlanmıştır. O sıralar Ankara'nın en önemli sorunu sıtma idi. Öyle ki, 1924 yılında Ankara'da sıtma oranı \% 100'e yakındı. Bakanlar Kurulu toplantısında bakanların çoğu çeşitli derecelerde sıtmalıydı. Atatürk, bunun mutlaka önüne geçileçğini belirterek; o zaman bataklık olan Atatürk Orman Çiftliği denilen sahayı üretim alanına dönüştürmüş, yine o zaman 20 bin dönümlük sahayı kapsayan ve sazlık olan Gençlik Parkı sahasını da sahibinden alarak dinlenme yeri yapmayı amaçlamıştır ${ }^{29}$.

Ankara'nın Şehirleşme Planı'nın yapılması için uluslararası proje yarışmasını Profesör Hermann Janssen kazanmıştır. Planın uygulanması için özellikle İçişleri Bakanı Şükrü Kaya'nın büyük yararları olmuş, İller Bankası'nın kurulması için bizzat öncülük etmiştir ${ }^{30}$.

${ }^{27}$ TBMM Zabıt Ceridesi, II. İntihap, c.II, Ankara (t.y.), s.665-670.; ayrıca bu konudaki tartışmalar için bkz., İsmet İnönü, Hatıralar, Yay. Haz. Sabahattin Selek, 2. Kitap, Ankara 1987, s.166-169 ve s.314.; Şerafettin Turan, Ismet Inönü Yaşamı, Dönemi ve Kişiliği, Ankara 2000, s.65-69.

${ }^{28}$ Falih Rıfkı Atay, Çankaya, Ankara 1984, s.419.

${ }^{29}$ İlhan Akçay. Ilden Ile Atatürk: Atatürk Ankara'da, Ankara (t.y.), s.96.

${ }^{30}$ Atay, a.g.e., s.421. 
Profesör Hermann Janssen, Atatürk'le ilk kez buluştuğu zaman bu projenin uygulanması için "Bir şehir planını tatbik edebilecek kadar kuvvetli bir iradeniz var mıdır?" diye sormuş, Atatürk bu söze çok kızarak "Koca memleketi yedi düvelin elinden kurtarmışız. Bir ortaçağ saltanatını yıkarak yerine bir yeniçă̆ devleti kurmuşuz. Bunca devrimler yapmaktayız. Bütün bunları bașaran bir rejimin bir sehir planin tatbik edebilecek kuvvette olup olmadı ̆̆ın nasıl sorabilirsiniz?" Profesör Hermann Janssen ise; "Belki sizin hakkınız var. Biz Almanya'da bile türlü güçlüklerle uğraşıyoruz da onun için sormuştum" demiştir ${ }^{31}$.

Ankara'nın Şehirleşme Planı'nda kullanılmak üzere Prof. Dr. Antal Réthly'den bilgi istenmiş, ${ }^{32}$ Prof. Dr. Antal Réthly de Ankara İklim Raporu'nu ${ }^{33}$ Temmuz 1927 'de hazırlamıs ve yetkililere sunmuștur. Ankara İklim Raporu, Ankara'nın şehirleşmesi konusunda çok büyük önem taşımakta ve günümüzde de bu önemini büyük ölçüde korumaktadır. Bu rapor şöyledir:

“Ankara'nın meteorolojik rasatlart ile ilgili raporumda şehrin, özellikle Etlik ve civarındaki dağlık sahalardan daha gayrî sihhî olduğunu belirtmiştim. Bu sonuca uzun yılların değil, yalnız bir yılın rasat malzemesi ile erişmiş bulunuyorum. Mühim iklim elemanı olan sisin önemini sırası gelmişken belirtmek isterim. Zira Etlik'te yapılan rasatlar görüslerimi kuvvetlendirmektedir.

Vadilerde; özellikle vadilerin nemli olmaları halinde veya büyük endüstri gelişmesi gösteren şehirlerde sis teşekkülü için en uygun şartlar mevcuttur. Açık gecelerde, bilhassa güneşin batışından sonraki şartlar, sis teşekkülü için çok müsaittir. Bu durumda, Kış mevsiminde sis tekerrürüne,

${ }^{31}$ Atay, a.g.e., s.422.

32 "Vekâlet-i Celilelerince ziraat kısmına ait olmak üzere mütehassıs raporları unvanı altında neșredilmiş bulunan 1927 tarihli kitabın 288'nci sahifesinde Ankara Ahval-i Havaiyesi'ne dair Prof. Réthly tarafından verilen malûmat meyanında 'iş bu rasadattan anlaşılıyor ki, Ankara'nın pek muzırr-ı sıhha olan iklimine mukabil civarının bilhassa Etlik'in iklimi pek iyidir' denilmektedir. Ankara'nın iklimleri hakkında kat'i ve sayan-ı dikkat bir hüküm itasının hangi esasat-ı fenniyeye istinat ettirilmiş bulunduğunun mumaileyh sahibi makaleden istifsariyle bu baptaki mütalâat-ı ilmiyelerinin iş'arına delâlet ve neticenin inha buyurulmasinı rica ederim efendim.

Sıhhye ve Muavenet-i İctimaiye Vekili Refik"

Buna istinaden Ziraat Vekili, Prof. Dr. Antal Réthly'den gerekli bilgiyi vermesini istemiştir: "Sthhtye ve Muavenet-i Íctimaiye Vekâleti Celilesinden varid olan 23.06.1927 tarihli tezkerenin bir suret-i masafdakası leffen tarafinıza irsal olunmuștur. Vekâlet-i müşarünileyhaya itay-ı malûmat edilmek üzere bu babtaki mütalâanızın bertafsil iș'arı rica olunur efendim.

Ziraat Vekili Sabri Bey"

${ }^{33}$ Dr. Antal Réthly, "Az Angorai Ködröl," Földneyi Közlimemyıl Bulletin de le Société Hongroise de Geographie Tome, c.LVI, Kötet 1928, s.105-109.; Dr. Antal Réthly, "A levegö nedvessége Angorában," Az Idöjàràs, Budapest 1927, s.44-46. 
Yazın tozun da (kuru sis) katıldığı Ankara güzel bir misal teşkil eder. Fabrikalardan çıkan yoğun dumanlarla ekseriye yoğunluğunu artıran tipik karasal bir sisle karşı karşıyayız. Şehrin kapalı, güneşin gayet güçlükle görülebileceği hal ve zamanlarda, Etlik'te günlük güneșlik bir havanın hüküm sürdüğüne bir çok defalar şahit oldum.

Eğer zamanında tedbir alınmazsa, aynı durumlarla her geçen sene daha fazlasıyla karşılaşılacaktır. Çünkü, sis veya duman sebebiyle, gelen güneş radyasyonunda daima bir azalış görülecektir. Şehrin nüfusunun çoğalması ve endüstriyel gelişme ile bacaların sayısı daima artmakta ve Ankara'da maalesef çok kötü kömür kullanılmaktadır. Kömürden hasıl olan işlerin bir kısmı uzun müddet yere düşmeden havada uçmaktadır. Havada sürüklenen $b u$ is parçacıkları yoğunlaşma çekirdeklerini meydana getirmekte, bu suretle ortaya çıkan sisler güneş radyasyonuna saatlerce perde çekmektedir. Karasal veya şehir sisi adını verdiğimiz bu sis, Dünya yüzeyinden sadece 16-20 kilometre yukarıya kadar uzanır. İște bu yükseklikten daha yükseklerde bulunan yerler bu güçlükle, özellikle oturulan yer olarak karşılaşmazlar. Etlik'in rüzgâr durumu ve şehre göre mevkî̂, senenin bir çok günlerinde burada temiz ve iyi havanın bulunmasına sebep olmaktadir.

Meseleye bir de radyasyon yönünden baktığımızda, bahçeye sahip olan Etlik etrafının, eğer su meselesi halledilebilirse, hava kürü ile en uygun tedavi yeri olarak seçilebilecek, sanatoryum inşaatı için uygun bir yer olacaktır.

1925 yılı Kasım ayından 1927 yılı Temmuz ayına kadar geçen 20 aylık zamanda, Etlik 29 gün sis altında kalmış, buna karşılık Ankara'da 380 gün sisli geçmiştir. Sislerin devam süresi hakkında bir şeyler söylemek mümkün olmamakla beraber, her sisli günde güneşin doğuşundan sonra ortalama olarak 3-5 saat devam ettiği kanaatindeyim. Isste, bu sis ve havanın kirlenmelerini dikkate aldı ̆̆ımızda, güneş ışınlarının pis hava tarafından nasıl tutulduğunu anlamış oluruz. Sisin hafif olması halinde de güneş ışınlarının yararlı ultraviyole kısmının hemen hemen büyük kısmı kaybedilmiş olur. Bu sebepler karşısında şehrin ikliminin iyi olmadığı sonucuna varmaktaylz.

Radyasyon durumları ve havada bulunan toz miktarı ile özel ölçümleri yapmak benim için imkânsız olmuştur. Gerek radyasyon ve gerekse havadaki toz miktarını ölçmenin yanı sıra Paris ve Budapeşte'de çok önceden beri yapılan havada sürüklenen bakteri ölçümlerini de yapmak şehrin lehine bir işolur.

Şehirde olduğu gibi, başta Etlik olmak üzere, civarında bu rasatlar yapılmış olsa idi, yukarıda söylediklerimin doğruluğu meydana çıkacaktı. Şehrin havasının kirliliği sadece sis, duman ve fabrika bacalarından çıkan islerden değil, keza havada sürüklenmekte olan fazla miktarda tozdan da 
meydana gelmektedir. Sehrin nüfusu ile yüzölçümü mukayese edildiğinde Ankara'nın oldukça yoğun bir süratle artan bir otomobil trafiğine sahip olduğu görülür.

Yollar oldukça kötü, hatta iyi yollarda dahi vesait geçişinden sonra muazzam toz bulutu görülür. Çok ince yapıda olan tozlar, saatlerce havada sürüklenip kalırlar. Mevcut yüksek sicaklık ve rutubet şartları altında su fışkırtmak yeter bir iş değildir. Bütün şehirlerde, bilhassa hükümet merkezlerinde güneşten gelen radyasyonu azaltan tozları asgariye indirmek ve keza havada sürüklenen bakterileri azaltmak için halkın sıhhati bakımından yollara büyük önem verilir. Hükümet merkezinde alınan tedbirlerin bütün memlekete örnek olması lâzım gelir.

Bütün hükümet müesseselerini Ankara'da toplamak yeterli değildir. Ancak, bütün sağlık şartlarının yerine getirilmesi halinde Ankara iyi bir başkent olmaya hak kazanır. Şimdiye kadar bu hususta çok şeyler yapılmıştır. Sitmaya karşı açılan kampanya hem çok önemli hem de yapıcı bir adım olmuştur. Çünkü, bu yolla bir kısım batak sahalar kuru vaziyete getirilmiş ve dolayısıyla sisli günlerin sayısı azaltılmıştır.

Kurutulan saha ve sisli gün sayısı azalması hususunda kantitatif bir delil gösterememekle beraber sis gün ve saat sayısının bir hayli azaldığından şüphemiz yoktur.

Şehrin süratle gelişmesi, sobaların ve bacaların artması ile sisli gün tekerrürü ve sisin yoğunluğu bir hayli artmış olacaktır.

Londra'da sisli günlerin sayısı 1871 ilâ 1890 periyodu arasında her beş senede aşağıda gösterildiği şekilde artış gösterdi. Illk beş senelik periyotta senede 51, ikinci beş senelik periyotta senede 58, üçüncüde senede 62 ve dördüncüde senede 74 gündür. Londra'da sise karşı kampanya açıldı ğından bu miktar gittikçe azalmaktadır.

Şehir civarındaki yerlerde de hava gün geçtikçe kirleniyor. Meselâ; 1750 yılında Greenwich'te öğle üzeri parlak güneşli gün sayıst senede 150 iken, aynı gün sayısı 1880'de 115'e düşmüş bulunuyor.

Sisli gün sayısının Viyana'da da süratle arttı̆̆ına işaret etmek isterim. Aşă̆ıdaki cetvelden bunu daha iyi anlayabiliriz.

Viyana'da Sisli Gün Sayısl

$$
\begin{array}{ccccc}
1801-1810 & 1811-1820 & 1821-1830 & 1831-1840 & 1841-1850 \\
36 & 65 & 67 & 110 & 125
\end{array}
$$

Klimatolojide senelik sis sayısı 25 'den az olan şehirlere sissiz veya çok az sisli şehir nazarı ile bakılır. Yıllık sis sayısı 50 ve daha fazla olan şehirler ise sisli şehir addedilir. Bu bakıma göre Ankara'y çok fazla sisli bir şehir kabul etmek gerekir. 
Kötü kömür, kötü yakıt ve bacaların kullanılması, havadaki sis miktarının artmasına sebep teşkil etmektedir.

Müsait olmayan klimatolojik bu durumlara karşı başarılı bir kampanya açmak mümkündür. Şayet aşağıdaki tavsiyeler yerine getirilirse sisli gün sayısı, toz bulutlu gün sayısı hayli azalmış olacaktır:

1. Şehir ve 6 kilometre etrafinı tozdan korumak için Belediye kanunla zorlanmalı ve bu mesafe dahilindeki yol ve sokaklar yă̆lanmall veya ziftle kaplanmalıdır.

2. Fabrikalar ve bacalar duman emici cihazlarla teçhiz edilmelidir. Avrupa'da büyük şehirlerin hepsinde bu durum kanunlaşmıştır.

3. Gelecekte fabrikalar, şehrin hakim rüzgârlarının fabrika toz ve dumanını getirmeyeceği yerlere kurulmalıdır.

Sağlık yönünden; dolayısıyla durumun bilimsel araştırılması sistematik olarak yerine getirilmelidir. Rasat istasyonu Etlik'te kalmalı ve ana istasyona paralel olarak rasatlar yapılmalıdır. Şehir yüksekten rasat edilmeli, güneşlenme müideti ve radyasyon ölçülmelidir.

Şuna kaniim ki, toz ve dumana karşı açılacak bir kampanya belki de dünyanın en tozlu başkentinin sağlık durumu bakımından çok önemli olacaktır.

Bu kampanya gayet temiz ve ultraviyole bakımından zengin olan bir hava teneffüiü için zarûridir.

Prof. Dr. Antal Réthly"

\section{Sonuç}

Bu rapora dayanarak 1920'lerin sonunda Ankara için; “Ĕger bana Ankara'nın Şehir Planı bakımından mecburi noktalar verilmemiş olsa idi, hiçbir zaman şehri bu çukura sokmaz, Etlik sırtlarına doğru kayardım." diyecektir.

Atatürk yeni bir devlet kurarken başkentin de yaşanabilir, olmasına dikkat etmiş ve imar faaliyetlerine girişmeden şehrin iklim şartlarına göre gelişmesinin ne şekilde olacağını bilimsel yöntemlerle tespit ettirmiştir. Prof. Dr. Antal Réthly'nin 1927'lerin dünyasında ve Türkiye'sindeki bu raporu oldukça dikkat çekicidir. Raporda yer alan tavsiyeler zaman içerisinde şehirleşmeye paralel olarak ihlâl edilmiş, bugün Ankara'daki şehirleşme o dönemin şehir plancısı Prof. Hermann Janssen'in planının tam olarak uygulanamaması sebebiyle çok değişik bir manzara arz etmektedir. 